\title{
Patient care and administrative activities of nurses in clinical/surgical units
}

\author{
Atividades assistenciais e administrativas do enfermeiro na clínica médico-cirúrgica
}

\author{
Marilia Moura Luvisotto ${ }^{1}$, Ana Carolina Vasconcelos ${ }^{2}$, Lívia Canelas Sciarpa ${ }^{3}$, Rachel de Carvalho ${ }^{4}$
}

\begin{abstract}
Objectives: To identify the administrative and nursing care activities most performed by nurses in clinical/surgical units and to determine which are most and least pleasant to them. Methods: A descriptiveexploratory field study, with a quantitative approach and with a sample made up of 40 nurses working in clinical/surgical units who answered a three-part questionnaire composed of identification data and characterization of the professional; a list of nursing and administrative activities for the nurse to grade according to the numbers: " $0=I$ do not perform it", "1 = I perform it occasionally", “2 = I perform it often", "3 = I perform it daily"; two open-ended questions, in which the nurse listed the activities he/she enjoyed the most and the least. Results: The administrative activities most performed by the nurses were: changing work shifts, preparing employee daily task charts and managing tests; the most performed nursing care activities were related to the stages of the Nursing Care Systematization and the interaction with the multi-professional team; the most enjoyable activities were direct patient care, patient evaluation and implementation of the systematization; the least enjoyable activities were administrative and bureaucratic routines, justification of complaints/problem-solving and preparation of employee task charts. Conclusion: Compared to administrative activities, nursing activities were performed most during the daily routine of the nurse, and the most enjoyable activities were those related to patient care, according to the opinions of the professionals.
\end{abstract}

Keywords: Nursing service, hospital/organization \& administration; Perioperative Nursing; Hospital care; Patient-centered care; Nurse's role

\section{RESUMO}

Objetivo: Identificar as atividades administrativas e assistenciais mais realizadas pelos enfermeiros nas clínicas médico-cirúrgicas e conhecer as mais e menos prazerosas para esses profissionais. Métodos: Pesquisa de campo descritivo-exploratória, com abordagem quantitativa, cuja amostra constituiu-se de 40 enfermeiros que trabalham em clínicas médico-cirúrgicas, os quais responderam a um questionário composto de três partes: dados de identificação e caracterização do profissional; relação de atividades assistenciais e administrativas para 0 enfermeiro, que deveria enumerar: " 0 = não realizo", "1 = realizo eventualmente", "2 = realizo moderadamente", "3 = realizo diariamente"; duas questões semiabertas, nas quais 0 enfermeiro listou as atividades que lhe eram mais e menos prazerosas. Resultados: As atividades administrativas mais realizadas pelos enfermeiros foram: passagem de plantão, escala diária e de tarefas de funcionários e gerenciamento de exames; as atividades assistenciais mais realizadas relacionavam-se às etapas da Sistematização da Assistência de Enfermagem e ao relacionamento com a equipe multiprofissional; as atividades mais prazerosas foram assistência direta ao paciente, avaliação do paciente e implementação da sistematização; as atividades menos prazerosas foram as rotinas administrativas e burocráticas, justificativa de queixas/resolução de problemas e realização de escalas de funcionários. Conclusão: As atividades assistenciais foram as mais realizadas, comparadas às atividades administrativas na rotina diária do enfermeiro, sendo também as mais prazerosas, segundo a opinião dos próprios profissionais.

Descritores: Serviço hospitalar de Enfermagem/organização \& administração; Enfermagem perioperatória; Assistência hospitalar; Assistência centrada no paciente; Papel do profissional de Enfermagem

\section{INTRODUCTION}

Nursing care has the objective of promoting, maintaining and recovering health of its clients, whether they are the patient, the family or the community. Thus, the idea of nursing care is implicit in nursing, since patient care is represented by services that should be offered with a great quality and by a specialist, not only from the ethical and humanistic points of view, but from the technical-scientific approach as well ${ }^{(1)}$.

\footnotetext{
Study carried out at Hospital Israelita Albert Einstein - HIAE, São Paulo (SP), Brazil.

${ }^{1}$ Nurse; Specialist in Clinical and Surgical Nursing at Faculdade de Enfermagem of Hospital Israelita Albert Einstein - HIAE, São Paulo (SP), Brazil.

${ }^{2}$ Nurse; Specialist in Clinical and Surgical Nursing at Faculdade de Enfermagem of Hospital Israelita Albert Einstein - HIAE, São Paulo (SP), Brazil.

${ }^{3}$ Nurse; Specialist in Clinical and Surgical Nursing at Faculdade de Enfermagem of Hospital Israelita Albert Einstein - HIAE, São Paulo (SP), Brazil.

${ }^{4} \mathrm{PhD}$; Professor at Faculdade de Enfermagem of Hospital Israelita Albert Einstein - HIAE, São Paulo (SP), Brazil.

Corresponding author: Marilia Moura Luvisotto - Rua Rocha Pombo, 343 - Jardim do Pilar - CEP 09185-750 - Santo André (SP), Brasil - Tel.: (11) 4426-9493 - e-mail: mariliaml@einstein.br

Received on May 28, 2009 - Accepted on Apr 12, 2010
} 
The nurse should have knowledge, experience and dynamism. He/she should base the work goals on the quality of the results and carry out his/her functions with efficiency and creativity. He/she should value people's qualities and have concern for the technical and scientific development of his/her employees. Additionally, he/she should maintain a good relationship with the leadership of the institution and with its employees, serving as a bridge between the two sides. Personal dignity and respect for the human being should be visible characteristics in a nurse's personality ${ }^{(2)}$.

The general skills of the nurse are also related to the administrative area, which includes decisionmaking, leadership and administration. Among the administrative functions, we highlight planning, organizing, coordinating and controlling of the healthcare services. Leadership involves commitment, responsibility, empathy, ability to make decisions and efficient and effective communication ${ }^{(3)}$.

In leadership, the nurse influences the actions of others for the establishment and attainment of objectives. This implies defining and planning nursing care within an interactive scenario. In order for the nurse to exert leadership, he/she needs to dominate and reconcile the use of principles and techniques of administration with principles and techniques that guide nursing care ${ }^{(4)}$.

According to law $n^{\mathbf{o}} 7498 / 86$, Regulation of Professional Exercise of the Regional Council of Nursing (COREN), the nurse carries out activities and is responsible for directing the nursing agency that is a part of the basic healthcare institution and leading the service and the nursing unit; organizing and directing the nursing services and its technical and auxiliary activities; planning, organizing, coordinating, executing and assessing the nursing care services; implementing nursing care systematization; offering direct patient care to severely ill patients with risk of death; providing nursing care of greater technical complexity that requires scientific knowledge and the capacity to make immediate decisions; participating in planning, executing and assessing the healthcare program and participating in the preparation, execution and assessment of healthcare plans ${ }^{(5)}$.

Reconciliation between the supervision and nursing care functions is considered a prerequisite for constructing the professional identity of the nurse, as well as for providing quality nursing care services to the patient ${ }^{(6)}$.

With the need to know the context of the administrative activities performed by the nurse, and the relationship between these with nursing care, this study had the objective of assessing the primary patient care and administrative functions developed by the nurses, seeking to comprehend their own perceptions of their actions.

\section{OBJECTIVES}

To identify the administrative and patient care activities performed more often by nurses in clinical/surgical units, and to determine the most and least enjoyable patient care and administrative activities carried out by nurses of clinical/surgical units, as per their own opinions.

\section{METHODS}

This was an exploratory and descriptive study, since it sought to obtain accurate information about a group in order to characterize it and evidence a profile ${ }^{(7)}$; a field study, because data collection happened at the site where the phenomena occured ${ }^{(8)}$; cross-sectional, since the data collection was to be made at a specific time point ${ }^{(7-8)}$; level I, which involved the denomination or classification of facts and events ${ }^{(8)}$, with a quantitative approach, in which statistical data represented empirical facts and events ${ }^{(7)}$.

The study was performed at the clinical/surgical units of the Hospital Israelita Albert Einstein (HIAE), a very large sized institution that has 500 beds and an equal number of nurses, in a general "one to one" ratio. The sample consisted of 40 nurses who work in the referred units. The inclusion criteria of the sample in the study were: to have been active in the clinical/surgical units for, at least, one year (nurses in training or junior nurses were not included); to perform administrative and patient-care activities; to consent to participate in the study, by signing the Informed Consent Form.

The data collection instrument (Appendix 1), constructed by the authors, was based on Bianchi's instrument ${ }^{(9)}$ and consisted of three parts. The first part contained data of identification and characterization of the nurse's profile. The second part contained a list of nursing care and administrative activities which the nurse was to enumerate according to the frequency in which they were performed: " $0=$ I do not perform it", " 1 = I perform it occasionally", " 2 = I perform it often", "3 = I perform it daily". The third part contained two open-ended questions in which the nurse was to list the activities that were most and least enjoyable.

The data were collected after approval of the project by the Scientific Committee of Faculdade de Enfermagem of Hospital Israelita Albert Einstein and by the Research Ethics Committee of the HIAE, with protocol no 0098.0.028.000-07.

The obtained data were statistically treated and presented in absolute numbers and percentages, using tables and charts.

\section{RESULTS}

Considering the study sample, composed of 40 nurses, after data collection by means of the questionnaire 
(Appendix 1), the results are presented, divided by characterization of the sample and administrative and nursing care activities most and least enjoyable carried out by these same professionals.

Most of the participating nurses $(37 ; 92.5 \%)$ were of the female gender.

As to the age of the interviewed nurses, the most of them $(25 ; 62.5 \%)$ are in the age group of $25-35$ years, in which $13(32.5 \%)$ were aged 25 to 30 years and 12 $(30 \%)$ were aged between 30 and 35 years (Table 1 ).

As to time of academic training of the participating nurses, $77.5 \%$ of the sample (31 professionals) had graduated 1 to 10 years before, and 17 of them $(42.5 \%)$ had graduated 5 to 10 years before (Table 2). The data relative to the age and time since graduation were considered consistent, since it was a sample composed primarily by young adults who had been in the job market from 1 to 10 years.

Regarding time of work at the clinical/surgical units, the vast majority $(34 ; 85 \%)$ had worked in this area for 1 to 10 years; $19(47.5 \%)$ of them had worked in this area from 1 to 5 years, and 15 of them $(37.5 \%)$ between 5 and 10 years (Table 3 ).

Considering the general skills of a nurse and having the goal of reaching the first objective of the study, we highlighted, in tables 4 and 5, the administrative and nursing care activities most often performed by them, as per the reports of the professionals who worked in the clinical/surgical units.
Table 1. Distribution of nurses per age group

\begin{tabular}{lcc}
\hline Age group & $\mathbf{n}$ & $\%$ \\
\hline $20 \mid-25$ years & 5 & 12.5 \\
$25 \mid-30$ years & 13 & 32.5 \\
$30 \mid-35$ years & 12 & 30 \\
$35 \mid-40$ years & 5 & 12.5 \\
$40 \mid-45$ years & 3 & 7.5 \\
$45 \mid-50$ years & 2 & 5 \\
\hline Total & 40 & 100 \\
\hline
\end{tabular}

Table 2. Distribution of nurses per time since graduation

\begin{tabular}{lcc}
\hline Time since graduation & $\mathbf{n}$ & $\%$ \\
\hline $01 \mid-05$ years & 14 & 35 \\
$05 \mid-10$ years & 17 & 42.5 \\
$10 \mid-15$ years & 4 & 10 \\
$15 \mid-20$ years & - & - \\
$20 \mid-25$ years & 4 & 10 \\
$25 \mid-30$ years & 1 & 2.5 \\
\hline Total & 40 & 100 \\
\hline
\end{tabular}

Table 3. Distribution of nurses per time of work in the clinical/surgical unit

\begin{tabular}{lcc}
\hline $\begin{array}{l}\text { Time of work in the } \\
\text { clinical/surgical unit }\end{array}$ & $\mathbf{n}$ & $\%$ \\
\hline $01 \mid-05$ years & 19 & 47.5 \\
$05 \mid-10$ years & 15 & 37.5 \\
$10 \mid-15$ years & 3 & 7.5 \\
$15 \mid-20$ years & 1 & 2.5 \\
$20 \mid-25$ years & 1 & 2.5 \\
$25 \mid-30$ years & 1 & 2.5 \\
\hline Total & 40 & 100 \\
\hline
\end{tabular}

Table 4. Administrative activities performed by nurses in clinical/surgical units

\begin{tabular}{|c|c|c|c|c|c|c|c|c|}
\hline \multirow[t]{2}{*}{ Administrative activities } & \multicolumn{2}{|c|}{$0=$ does not perform it } & \multicolumn{2}{|c|}{$1=$ performs it occasionally } & \multicolumn{2}{|c|}{$2=$ often performs it } & \multicolumn{2}{|c|}{$3=$ performs it daily } \\
\hline & $n$ & $\%$ & $n$ & $\%$ & $n$ & $\%$ & $n$ & $\%$ \\
\hline Change of shifts & - & - & - & - & - & - & 40 & 100 \\
\hline Daily employee shifts and tasks & - & - & - & - & 4 & 10 & 36 & 90 \\
\hline $\begin{array}{l}\text { Employee rotation shifts for } \\
\text { time-off and vacations }\end{array}$ & 12 & 30 & 17 & 42.5 & 11 & 27.5 & - & - \\
\hline Employee evaluation & 8 & 20 & 16 & 40 & 12 & 30 & 6 & 15 \\
\hline Employee training & 6 & 15 & 10 & 25 & 20 & 50 & 4 & 10 \\
\hline Participation in meetings & - & - & 4 & 10 & 30 & 75 & 6 & 15 \\
\hline Preparation of scientific studies & 8 & 20 & 30 & 75 & 1 & 2.5 & 1 & 2.5 \\
\hline Management of tests & - & - & 1 & 2.5 & 5 & 12.5 & 34 & 85 \\
\hline
\end{tabular}

Table 5. Nursing care activities performed by nurses in clinical/surgical units

\begin{tabular}{|c|c|c|c|c|c|c|c|c|}
\hline \multirow[t]{2}{*}{ Nursing care activities } & \multicolumn{2}{|c|}{$0=$ does not perform it } & \multicolumn{2}{|c|}{1 = performs it occasionally } & \multicolumn{2}{|c|}{$2=$ often performs it } & \multicolumn{2}{|c|}{$3=$ performs it daily } \\
\hline & $\mathbf{n}$ & $\%$ & $\mathbf{n}$ & $\%$ & $\mathbf{n}$ & $\%$ & $\mathbf{n}$ & $\%$ \\
\hline Nursing clinical history-taking & - & - & 1 & 2.5 & 9 & 22.5 & 30 & 75 \\
\hline Physical examination & - & - & - & - & 2 & 5 & 38 & 95 \\
\hline Nursing progress notes & - & - & - & - & - & - & 40 & 100 \\
\hline Nursing prescription & - & - & - & - & - & - & 40 & 100 \\
\hline Patient admission and discharge & - & - & - & - & 5 & 12.5 & 35 & 87.5 \\
\hline Supervisions of delivered nursing care & - & - & - & - & 2 & 5 & 38 & 95 \\
\hline Interaction with the multiprofessional team & - & - & - & - & - & - & 40 & 100 \\
\hline
\end{tabular}


In relation to the second objective, tables 6 and 7 represent the most and least enjoyable activities performed by nurses, according to their own opinions.

Table 6. Most pleasant daily activities performed by nurses in the clinical/surgical units

\begin{tabular}{|c|c|c|}
\hline Most pleasant activities & Number of answers* & $\%$ \\
\hline Direct patient care & 23 & 19.8 \\
\hline Patient evaluation & 22 & 19.0 \\
\hline $\begin{array}{l}\text { Implementation of the nursing care systematization } \\
\text { (SAE) }\end{array}$ & 17 & 14.7 \\
\hline Orientation/education for patients and their families & 12 & 10.4 \\
\hline Training/supervision of employees & 12 & 10.4 \\
\hline Case discussion with the multi-professional team & 10 & 8.6 \\
\hline Scientific research/case study & 4 & 3.4 \\
\hline Team work & 4 & 3.4 \\
\hline Change of shift & 3 & 2.6 \\
\hline Applying protocols & 2 & 1.7 \\
\hline Humanized care/support to patients & 2 & 1.7 \\
\hline Charts of employee daily work shifts & 2 & 1.7 \\
\hline Negotiation among sectors & 2 & 1.7 \\
\hline Organizing the sector & 1 & 0.9 \\
\hline Total number of answers & 116 & 100 \\
\hline
\end{tabular}

Table 7. Least pleasant daily activities performed by nurses in the clinical/surgical units

\begin{tabular}{lcc}
\hline Least pleasant activities & Number of answers* & \% \\
\hline Administrative and bureaucratic routines & 21 & 23.9 \\
Justification of complaints/problem-solving & 17 & 19.3 \\
Preparation of employee task charts & 16 & 18.2 \\
Negotiating the employee work shifts & 9 & 10.2 \\
Forecast and replenishment of materials and equipment & 9 & 10.2 \\
Team conflicts & 4 & 4.5 \\
Direct patient care & 3 & 3.4 \\
Accompanying medical visits & 2 & 2.3 \\
Employee evaluation & 2 & 2.3 \\
Organizing the sector & 2 & 2.3 \\
Change of shift & 2 & 2.3 \\
Nursing prescription & 1 & 1.1 \\
\hline Total number of answers & 88 & 100 \\
\hline
\end{tabular}

* The number of answers exceeds the number of subjects because each participant could give up to three answers.

\section{DISCUSSION}

Analyzing the results overall, nursing care activities were performed most often and were also the most enjoyable relative to administrative activities, in the opinion of the nurses who participated in the study.

The most often performed administrative activity by the nurses was work shift exchange, which was the only thing that all reported doing daily. Next were the preparing charts of employee daily work shifts and tasks and managing tests.

On the other hand, the least performed administrative activities were employee time-off and vacation charts, employee evaluation, replenishment and control of materials and equipment and preparation of scientific studies.
According to experts on the subject(10-11), the administrative activities of nurses include helping in the transition from one work shift to another; controlling consistent attendance, punctuality and discipline of employees; drawing up monthly work charts and time off/vacation rotations of employees; organizing and participating in the continued education program; performing employee assessments; controlling equipment, materials and medications; promoting periodic meetings; participating in research in the area of nursing; leading, giving orientation and supervising the nursing team. Thus, we verified agreement between the activities carried out by the nurses in this study and those recommended in literature.

In practical terms, we observed that some activities, such as work shift rotations and management of tests (scheduling, patient preparation, certification of availability of time slots and evaluation of the results), are a part of the nursing care given directly to the patient, and may be characterized as nursing care activities. Nevertheless, in the literature researched, these actions are inserted as administrative tasks, since they are a part of patient care management.

Regarding patient care activities performed by the nurse in clinical/surgical units, we noted that all those described were performed daily by the nursing professional, and the entire sample responded that they did updatings on patients' clinical progression and nursing prescriptions and interaction with the multiprofessional team on a daily basis.

Within this context, data in literature consider ${ }^{(10)}$ that the main nursing care activities performed by the nurse include history-taking, prescription and nursing clinical progress reports; direct nursing care to patients who were more severely ill; performance of private nursing procedures; supervision of nursing care given by the nursing team; identification and quick decisionmaking in face of non-routine situations in the unit; daily orientation of the nursing professional as to the performance of procedures.

The results of this study demonstrate that nurses were involved in the performance of the phases of the nursing process, which compose the independent activities of the professional and are instituted at the hospital where the investigation took place. On the other hand, one cannot omit considering that, despite those who responded that they often perform a partial physical examination, this stage in a sine qua non condition for carrying out the two previous activities.

We observed that, despite the fact that the nurse performs, during his/her routine, nursing care and administrative activities, the activities carried out daily are, for the most part, those of nursing care. 
There is no dichotomy between nursing care and administrative functions performed by the nurse, since they complement each other. It is believed that the nurse is the administrator/manager of nursing care given to the patient, since the exercise of this function is centered on nursing care, including the management of human resources, materials and necessary facilities for the adequate treatment given to the client and his/ her family ${ }^{(12)}$.

The performance of these activities (nursing care and administrative), with dedication and competence, directly reflects the quality of nursing care given to the entire clientele who seeks Healthcare services.

Currently, there is an increase in the number of nurses involved with nursing care, but, in the area of management, the role of the nurse has increased as to providing orientation on routines, norms and responsibilities applied to his/her team ${ }^{(13)}$. This fact may be confirmed by the high rate of daily orientations to the patient and the families and actions of supervision of the provided nursing care.

The present study further identified that the most pleasant daily activities carried out by nurses of the clinical/surgical units were direct patient care, evaluation of the nursing care given and implementation of the Nursing Care Systematization (SAE, acronym in Portuguese), besides orientation of the patient and his/ her family, training and supervision of employees and case discussion with the multi-professional team.

The least enjoyable daily activities performed by the nurses of the clinical/surgical units, according to their own opinions, were administrative and bureaucratic activities, justifications of complaints and problemsolving, preparation of employee rotations, among others.

We verified that the performance of nursing care activities were more enjoyable for nurses than the administrative tasks in the clinical/surgical units.

In a study performed with nurses from the surgical center of the same institution, we noted that among the least pleasant activities were employee rotation charts, request and verification of materials, and nonperformance of direct patient-care, such as venous puncture and changing bandaging/dressings. The nurses reported that they would like to be able to perform these actions $^{(14)}$. Thus, we noted that even in different sectors of the hospital, the most and least pleasant activities for nurses were similar.

We point out the emergence of studies related to the theme, especially in national literature, since our bibliographic search led us to articles that discuss the role of the nurse as manager/leader of teams or sectors, primarily related to specialties, and not in relation to performance in clinical/surgical inpatient units.
With this study, it was possible to identify the primary functions of the nurse in the clinical/surgical units, noting that, besides being more enjoyable, nursing care activities were more often performed by the nurses of the sample.

We know that the nursing care and administrative activities are a part of the necessary skills for nursing, aiming for excellence in the quality of nursing care offered to the client and family members that accompany the patient during the hospitalization process.

\section{CONCLUSIONS}

The analysis of the obtained data by means of the questionnaires answered by 40 nurses of the clinical/ surgical units allowed us to conclude that:

- patient-care activities were more frequently performed relative to the administrative activities in the daily routine of nurses;

- the most often performed administrative activities were transition of work shifts, daily rotations and employee task charts and management of tests;

- the most frequently carried out patient-care activities were implementation of the SAE (nursing clinical progress and prescription) and interaction with the multi-professional team;

- the nursing care activities were more enjoyable than administrative actions for the nurses;

- the most pleasant activities were direct patient care, patient assessment and implementation of the SAE;

- the least pleasant activities were administrative and bureaucratic routines, justifications of complaints/ problem-solving and preparation of employee rotations.

\section{REFERENCES}

1. Carvalho R. Instrumentação cirúrgica: processo ensino-aprendizagem por alunos de graduação em enfermagem [tese]. São Paulo: Universidade de São Paulo; 2002.

2. Marx LC, Morita LC. Manual de gerenciamento de enfermagem. São Paulo: Rufo; 1998.

3. Peres AM, Ciampone MHT. Gerência e competências gerais do enfermeiro. Texto \& Contexto Enferm. 2006;15(3):492-9.

4. Trevizan MA. Liderança do enfermeiro: 0 ideal e o real no contexto hospitalar. São Paulo: Sarvier; 1993.

5. Brasil. Lei n. 7.498, de 25 de junho de 1986. Dispõe sobre a regulamentação do exercício da Enfermagem e dá outras providências [Internet]. Brasília (DF): Diário Oficial da República Federativa do Brasil; 1986 [citado 2009 Maio 22]. Disponível em: http://www.portalcofen.gov.br/2007/materias. asp?ArticlelD $=22$ 乏ion $\mid \mathrm{D}=35$

6. Martin J, Valentim A. Supervisão de enfermagem $x$ assistência ao paciente: compatibilização como pressuposto à identidade profissional e à qualidade da assistência. Nursing (São Paulo). 2000;3(26):16-7

7. Brevidelli MM, Domenico EBL. Trabalho de conclusão de curso: guia prático para docentes e alunos da área da saúde. 2a ed. São Paulo: látria; 2008. 
8. Polit DF, Beck CT, Hungler BP. Fundamentos de pesquisa em enfermagem. 3a ed. Porto Alegre: Artmed; 2004.

9. Bianchi ERF. Stress entre enfermeiros hospitalares [tese]. São Paulo: Universidade de São Paulo;1999.

10. Motta ALC. Normas, rotinas e técnicas de enfermagem. 4a ed. São Paulo: látria; 2003.

11. Marquis BL, Huston CJ. Administração e liderança em enfermagem: teoria e prática. 4a ed. Porto Alegre: Artmed; 2005.
12. Melo MRAC, Fávero N, Trevizan MA, Hayashida M. Expectativa do administrador hospitalar frente às funções administrativas realizadas pelo enfermeiro. Rev Latino-Am Enfermagem. 1996:4(1):131-44.

13. Silva $\mathrm{CP}$, Juliani $\mathrm{CM}$. Funções administrativas do enfermeiro no contexto hospitalar [resumo TC-6]. einstein. 2007;5(Supl 1):S3-S4. [Apresentado no IV Simpósio Internacional de Enfermagem; 2007 Set 26-28; São Paulo, SP].

14. Silva MR, Carvalho R. Atuação do enfermeiro no centro cirúrgico. $7^{\circ}$ Congresso Brasileiro de Enfermagem em Centro Cirúrgico, Recuperação Anestésica e Centro de Material e Esterilização; 2005 Julho 30-Agosto 2; Anais. São Paulo; 2005.

Appendix 1. Data collection instrument

\section{PATIENT CARE AND ADMINISTRATIVE ACTIVITIES OF THE NURSE}

I- Identification data

1. Gender: female ( )

male ( )

2. Age: years

3. Time since graduation: years

4. Time of work in the clinical/surgical unit: years.

II - Administrative and patient care activities of the nurse

The chart below contains a list of administrative activities and another one with patient care activities. Number each activity according to the frequency in which you perform it, using the key:
$0=1$ do not perform it
$1=\mid$ perform it occasionally
$2=I$ often perform it
$3=$ I perform it daily

\begin{tabular}{|l|l|l|l|l|l|l|l|l|l|}
\hline Administrative Activities & $\mathbf{0}$ & $\mathbf{1}$ & $\mathbf{2}$ & $\mathbf{3}$ & Nursing care Activities & $\mathbf{0}$ & $\mathbf{1}$ & $\mathbf{2}$ & $\mathbf{3}$ \\
\hline Change of shifts & & & & & Nursing clinical history-taking & & \\
\hline Daily employee shifts and tasks & & & & & Physical examination & & & \\
\hline Employee rotation shifts for time-off and vacations & & & & & Nursing progress notes & & & \\
\hline Employee evaluation & & & & & Nursing prescription & & \\
\hline $\begin{array}{l}\text { Forecast, replenishment and control of materials and } \\
\text { equipment }\end{array}$ & & & & & Patient admission and discharge & & \\
\hline Employee training & & & & & Technical procedures & & \\
\hline Participation in meetings & & & & & Orientation of patients and their families & & \\
\hline Preparation of scientific studies & & & & & Supervisions of nursing care given & & \\
\hline Management of tests & & & & & Interaction with the multiprofessional team & & & \\
\hline Others & & & & & & & & \\
\hline
\end{tabular}

III - Most and least pleasant activities

1. Describe three activities that you perform in your daily tasks that provide you with the most pleasure:

2. List three activities that you perform in your daily tasks that provide you with the least amount of pleasure: 